\title{
PEMBELAJARAN KOOPERATIF TIPE STAD UNTUK MENINGKATKAN AKTIVITAS DAN HASIL BELAJAR TIK SISWA KELAS XI BAHASA SMA NEGERI 3 SINGARAJA TAHUN AJARAN 2009/2010
}

\author{
Oleh \\ Ni Wayan Yuni \\ Jurusan Pendidikan Teknik Informatika, FTK, UNDIKSHA
}

\begin{abstract}
ABSTRAK
Tujuan dari penelitian ini adalah untuk (1) meningkatkan aktivitas belajar siswa dan (2) meningkatkan hasil belajar siswa dalam pelajaran TIK melalui implementasi model pembelajaran kooperatif tipe STAD.

Penelitian ini merupakan Penelitian Tindakan Kelas (PTK) yang melibatkan subjek sebanyak 43 orang siswa kelas XI Bahasa ${ }_{1}$ SMA Negeri 3 Singaraja pada tahun ajaran 2009/2010. Objek penelitian ini adalah (1) aktivitas belajar siswa dan (2) hasil belajar siswa terhadap pelajaran TIK. Penelitan ini berlangsung ke dalam dua siklus pembelajaran dengan tahap-tahap tiap siklus adalah (1) perencanaan, (2) tindakan, (3) observasi/ evaluasi, dan (4) refleksi. Jenis data yang dikumpulkan adalah data mengenai (1) aktivitas belajar siswa dan (2) hasil belajar siswa. Data aktivitas belajar siswa dikumpulkan dengan menggunakan metode observasi, sedangkan data hasil belajar siswa dikumpulkan dengan menggunakan metode tes dan observasi. Data yang telah terkumpul selanjutnya dianalisis secara deskriptif.

Hasil penelitian menunjukkan bahwa (1) implementasi pembelajaran kooperatif tipe STAD dapat meningkatkan aktivitas belajar siswa, yaitu dari 3,8 dengan kategori cukup aktif pada siklus I menjadi 6,0 dengan kategori aktif pada siklus II, (2) implementasi pembelajaran kooperatif tipe STAD dapat meningkatkan hasil belajar siswa, yaitu pada siklus I rata-rata $(\bar{X})$ hasil belajar siswa diperoleh sebesar 77,0 dengan kategori tuntas meningkat pada siklus II menjadi 82,7 dengan kategori tuntas, daya serap (DS) siswa pada siklus I diperoleh sebesar 77,0\% dengan kategori tuntas meningkat menjadi $82,7 \%$ dengan kategori tuntas pada siklus II, dan ketuntasan klasikal (KK) pada siklus I diperoleh sebesar 68,3\% dengan kategori tidak tuntas kemudian meningkat pada siklus II menjadi 90,0\% dengan kategori tuntas.
\end{abstract}

Kata-kata kunci: model pembelajaran kooperatif STAD, aktivitas belajar, hasil belajar TIK.

\section{ABSTRACT}

This study aimed at (1) improving students' learning activity and (2) improving students' achievement in TIK subject through the implementation of Cooperative Learning STAD type. 
This is a classroom action research which involved 43 students of XI Language program of SMA Negeri 3 Singaraja in the academic year of 2009/2010 as the subject. Object of this study are (1) students' learning activity (2) students' achievement in TIK subject. This study was held in 2 cycles. Every cycle consists of (1) planning, (2) treatment, (3) observation/ evaluation, (4) reflection. Data gained was about (1) students' learning activities and (2) students' learning achievement. Data about students' learning activities was taken with observation method, and students' learning achievement was taken with test and observation method also. The data was analyzed descriptively.

The result of this study are (1) The implementation of Cooperative Learning STAD type could increase students' activities in learning, from 3,8 in quite enough category in cycle I, become 6,0 in active category in cycle II, (2) the implementation of cooperative learning STAD type could increase students' learning achievement, in cycle I the mean score was 77,0 with complete category increase into 82,7 in cycle II with complete category also. Absorptivity of the students in cycle I was $77 \%$. It was increased in cycle II become $82,7 \%$ with complete category. Classical Completeness in cycle I was 68,3\% in incomplete category become $90 \%$ in cycle II in complete category.

Keywords: Cooperative Learning STAD type, learning activities, TIK learning achievement.

\section{PENDAHULUAN}

Proses belajar mengajar yang berlangsung di sekolah tidak dapat lepas dari peran seorang guru. Guru merupakan salah satu faktor yang sangat berperan dalam meningkatkan kualitas anak didiknya, dalam UU Sisdiknas No. 20 Tahun 2003 Pasal 39 ayat 2 jelas terurai bahwa: "Pendidik merupakan tenaga profesional yang bertugas merencanakan dan melaksanakan proses pembelajaran, menilai hasil pembelajaran, melakukan pembimbingan dan pelatihan, serta melakukan penelitian dan pengabdian kepada masyarakat, terutama bagi pendidik pada perguruan tinggi."

Guru sebagai tenaga profesional mempunyai tangggung jawab untuk mentransformasikan ilmu pengetahuan dan nilai-nilai kepada siswa dengan mengedepankan etika kerja, bebas dari tekanan pihak luar, produktif, efisein, dan inovatif yang didasari oleh unsur-unsur ilmu dan teori yang sistematis. Seorang guru tidak jarang mengalami masalah dalam melakukan proses belajar mengajar. Masalah yang dihadapi guru dapat bersumber dari dalam diri guru atau bersumber dari luar guru itu sendiri. Salah satu masalah yang bersumber dari guru adalah 
penerapan pembelajaran yang lebih didominasi oleh peran guru. Guru lebih banyak menempatkan siswa sebagai objek dan bukan sebagai subjek pembelajaran, sehingga menyebabkan rendahnya aktivitas dan hasil belajar siswa. Setting pembelajaran seperti ini juga terjadi pada mata pelajaran Teknologi Informasi dan Komunikasi (TIK), apalagi mata pelajaran TIK merupakan mata pelajaran yang tergolong baru dalam kurikulum.

Berdasarkan dokumentasi dan hasil wawancara yang dilakukan terhadap guru TIK di SMA Negeri 3 Singaraja didapat bahwa rerata kelas, daya serap dan ketuntasan belajar secara klasikal kelas XI Bahasa $1_{1}$ tahun ajaran 2008/ 2009 semester I dan II seperti yang terjabar pada Tabel 1.1.

Tabel 1. Rerata kelas, daya serap, dan ketuntasan klasikal kelas XI Bahasa tahun ajaran 2008/ 2009 semester I dan II.

\begin{tabular}{|c|c|c|c|}
\hline Semester & Rerata Kelas & Daya Serap & Ketuntasan Klasikal \\
\hline I & 74,01 & $74,01 \%$ & $66,67 \%$ \\
\hline II & 73,68 & $73,68 \%$ & $67,57 \%$ \\
\hline
\end{tabular}

Sumber : rekapitulasi hasil belajar siswa kelas XI Bahasa ${ }_{1}$ SMA Negeri 3 Singaraja tahun ajaran 2008/2009

Berdasarkan Tabel 1 di atas terlihat bahwa rerata kelas, daya serap, dan ketuntasan klasikal siswa kelas XI Bahasa ${ }_{1}$ tahun ajaran 2008/ 2009 masih di bawah Kriteria Ketuntasan Minimal (KKM), yang mana KKM untuk rerata kelas adalah 75, daya serap adalah 75\%, dan untuk ketuntasan klasikal adalah 85\%. Belum optimalnya hasil belajar siswa di SMA Negeri 3 Singaraja, memerlukan perhatian semua pihak untuk mencari faktor penyebab beserta solusinya. Berdasarkan hasil observasi dan wawancara dengan guru pengajar TIK SMA Negeri 3 Singaraja diperoleh beberapa masalah yang perlu dicermati. Beberapa masalah tersebut di antaranya yaitu:

Pertama, berdasarkan dokumentasi hasil belajar siswa pada tahun ajaran 2008/ 2009 tercatat bahwa hasil belajar TIK siswa kelas XI Bahasa ${ }_{1}$ di bawah KKM sekolah. Hasil belajar dapat dilihat pada Tabel 1.1 sebelumnya. 
Kedua, dari hasil observasi kegiatan belajar mengajar di kelas diperoleh bahwa sistem pembelajaran lebih didominasi oleh peran guru. Guru lebih banyak menempatkan siswa sebagai objek dan bukan sebagai subjek pembelajaran.

Ketiga, dalam proses belajar mengajar, guru belum pernah menerapkan model pembelajaran kooperatif, sehingga dalam proses pembelajaran kurang terjadi interaksi antara guru-siswa, siswa-guru, atau siswa-siswa.

Keempat, pola pikir siswa dalam proses pembelajaran masih perlu diarahkan. Dalam proses pembelajaran siswa cenderung pasif.

Kelima, masih ditemukan siswa yang tidak menyiapkan diri sebelum pelajaran dimulai.

Berdasarkan dari uraian masalah pembelajaran di atas, solusi yang dapat dilakukan agar pembelajaran dapat berjalan optimal dan mampu meningkatkan aktivitas dan hasil belajar siswa adalah diperlukanya suatu penerapan model pembelajaran yang inovatif. Salah satu contoh pembelajaran inovatif adalah pembelajaran kooperatif. Pembelajaran kooperatif merupakan model pembelajaran yang mengkondisikan kelas ke dalam kelompok-kelompok kecil yang heterogen (Santyasa dan Sukadi, 2007: 30-31).

Bertolak dari permasalahan dan keunggulan model pembelajaran kooperatif, peneliti mencoba memberikan alternatif pemecahan masalah untuk meningkatkan aktivitas dan hasil belajar siswa kelas XI Bahasa ${ }_{1}$ SMA Negeri 3 Singaraja melalui penerapkan model pembelajaran kooperatif tipe Student Team Achievement Division (STAD). STAD dikembangkan oleh Robert Slavin dan temantemanya di Universitas John Hopkin. STAD merupakan teknik pembelajaran kooperatif yang paling sederhana. Siswa dalam satu kelas dibagi menjadi kelompokkelompok beranggotakan 4-5 orang. Setiap kelompok harus heterogen, terdiri dari laki-laki dan perempuan, berasal dari berbagai suku, dan memiliki kemampuan akademik tinggi, sedang, dan rendah (Santyasa dan Sukadi, 2007: 39).

Permasalahan yang dikaji dalam penelitian ini adalah bagaimana aktivitas dan hasil belajar siswa dalam pelajaran TIK melalui implementasi pembelajaran

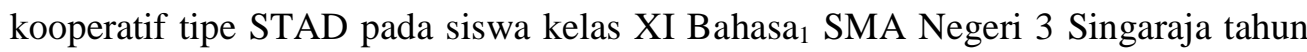
ajaran 2009/2010?. Tujuan dari penelitian ini adalah untuk meningkatkan aktivitas 
dan hasil belajar siswa kelas XI Bahasa ${ }_{1}$ SMA Negeri 3 Singaraja dalam pelajaran TIK melalui implementasi pembelajaran kooperatif tipe STAD. Manfaat yang diharapkan peneliti dari penelitian ini tertuju kepada siswa, guru, sekolah tempat melaksanakan tindakan, peneliti, dan peneliti pendidikan lainnya.

\section{METODE PENELITIAN}

Penelitian ini merupakan Penelitian Tindakan Kelas (Classroom Action Research), yaitu suatu penelitian yang dilakukan di kelas dengan tindakan-tindakan tertentu agar dapat memperbaiki atau meningkatkan kualitas pembelajaran. Subjek yang diberi tindakan dalam penelitian ini adalah siswa kelas XI Bahasa ${ }_{1}$ SMA Negeri 3 Singaraja tahun ajaran 2009/2010 yang berjumlah 43 siswa, sedangkan objek dari penelitian ini adalah aktivitas dan hasil belajar siswa dalam pelajaran TIK.

Penelitian ini dilaksanakan ke dalam dua siklus pembelajaran dengan tahap-tahap tiap siklus adalah: (1) perencanaan, (2) tindakan, (3) observasi/ evaluasi, dan (4) refleksi. Adapun rancangan tahapan penelitian seperti Gambar 1.

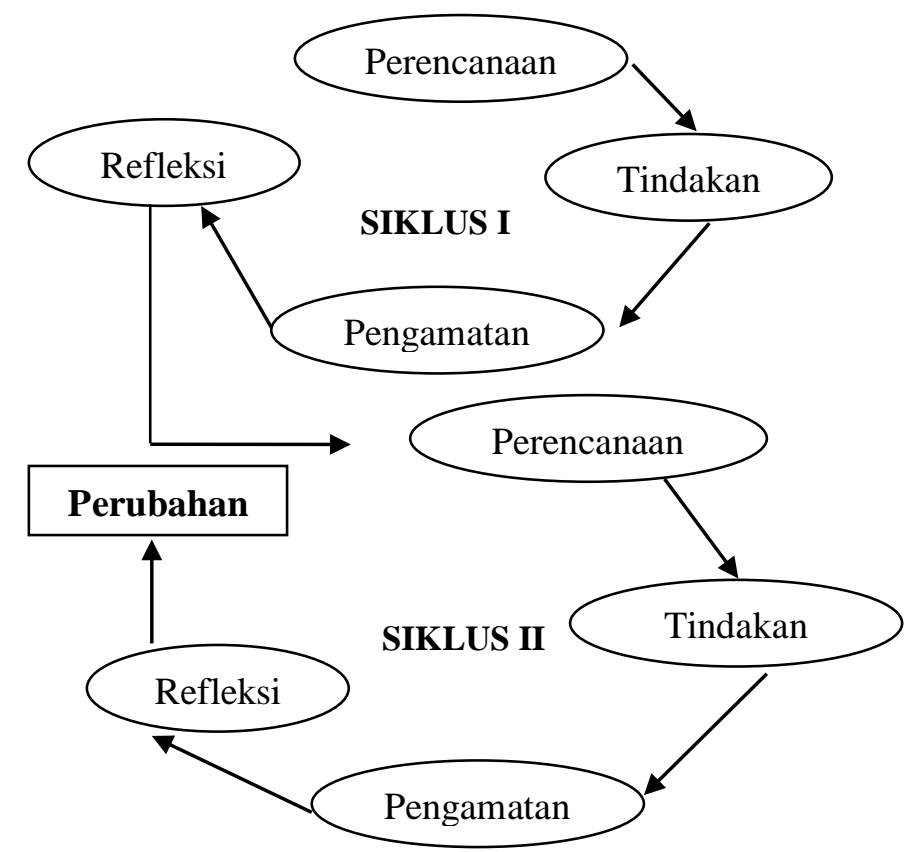

Gambar 1. Rancangan Penelitian Tindakan Kelas

(Kusumah dan Dedi Dwitagama, 2009: 44) 
Data yang dikumpulkan untuk dianalisis dalam penelitian ini adalah aktivitas dan hasil belajar siswa selama diimplementasikannya model pembelajaran kooperatif tipe STAD. Instrumen dan teknik pengumpulan data yang digunakan dalam penelitian ini dapat dilihat pada Tabel 2.

Tabel 2.Instrumen dan Teknik Pengumpulan Data

\begin{tabular}{|c|c|c|c|c|c|}
\hline No. & Jenis Data & $\begin{array}{c}\text { Sumber } \\
\text { Data }\end{array}$ & Metode & Instrumen & Waktu \\
\hline 1 & $\begin{array}{c}\text { Aktivitas } \\
\text { Belajar Siswa }\end{array}$ & Siswa & Observasi & $\begin{array}{c}\text { Lembar } \\
\text { Pedoman } \\
\text { Observasi }\end{array}$ & $\begin{array}{c}\text { Selama } \\
\text { Pelaksanaan } \\
\text { Tindakan }\end{array}$ \\
\hline \multirow{2}{*}{2} & $\begin{array}{l}\text { Hasil Belajar } \\
\text { Siswa } \\
\text { a. Aspek } \\
\text { Kognitif }\end{array}$ & Siswa & Tes & $\begin{array}{c}\text { Tes Aspek } \\
\text { Kognitif }\end{array}$ & $\begin{array}{c}\text { Pembelajaran } \\
\text { dan Akhir } \\
\text { Siklus I dan II }\end{array}$ \\
\cline { 2 - 6 } & $\begin{array}{l}\text { b. Aspek } \\
\text { Psikomotor }\end{array}$ & Siswa & Observasi & $\begin{array}{c}\text { Lembar } \\
\text { Observasi } \\
\text { Psikomotor }\end{array}$ & $\begin{array}{c}\text { Selama } \\
\text { Pelaksanaan } \\
\text { Tindakan }\end{array}$ \\
\cline { 2 - 6 } & $\begin{array}{l}\text { c. Aspek } \\
\text { Afektif }\end{array}$ & Siswa & Observasi & $\begin{array}{c}\text { Lembar } \\
\text { Observasi } \\
\text { Afektif }\end{array}$ & $\begin{array}{c}\text { Selama } \\
\text { Pelaksanaan } \\
\text { Tindakan }\end{array}$ \\
\hline
\end{tabular}

Teknik analisis data dan kriteria keberhasilan tindakan untuk masingmasing data yang dikumpulkan adalah sebagai berikut.

a. Aktivitas Belajar Siswa

Data aktivitas belajar siswa yang dianalisis ada tiga jenis aktivitas belajar yang terdiri dari 8 deskriptor, sehingga dapat ditentukan skor tertinggi adalah 8 dan skor terendah adalah 0 . Nilai aktivitas belajar yang diperoleh siswa dirata-ratakan dengan menggunakan persamaan 1.

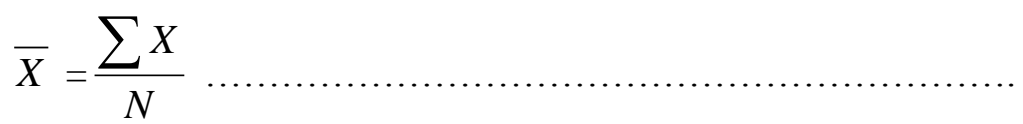

Keterangan:

$$
\begin{aligned}
& \bar{X} \quad=\text { rata-rata aktivitas belajar siswa (klasikal) } \\
& \sum X=\text { jumlah seluruh aktivitas belajar siswa secara individu } \\
& N \quad=\text { banyaknya siswa }
\end{aligned}
$$

(Dimodifikasi dari Sudjana, 2005:109) 
Kemudian hasil perataan aktivitas belajar siswa dikategorikan ke dalam lima (5) kelas interval. Kelas interval untuk masing-masing kategori tersebut ditentukan dengan persamaan 2 .

$$
\begin{aligned}
\mathrm{I} & =\frac{\text { Range }}{\text { Jumlah Interval Kelas }} \\
\mathrm{I} & =\frac{\text { Skor Maksimum }- \text { Skor Minimum }}{\text {......... }} \\
& =\frac{8-0 \text {. } 0}{5}=1,6
\end{aligned}
$$

Keterangan :

$$
\mathrm{I}=\text { Interval aktivitas belajar siswa }
$$

(Dimodifikasi dari Nasir, 2003:380 )

Pedoman penggolongan aktivitas belajar siswa pada implementasi pembelajaran kooperatif tipe STAD dalam pelajaran TIK dinyatakan dengan Tabel 3.

Tabel 3. Pedoman Penggolongan Aktivitas Belajar Siswa

\begin{tabular}{|c|c|c|}
\hline No & Kriteria & Kategori \\
\hline 1 & $6,4 \leq \bar{X} \leq 8$ & Sangat Aktif \\
\hline 2 & $4,8 \leq \bar{X}<6,4$ & Aktif \\
\hline 3 & $3,2 \leq \bar{X}<4,8$ & Cukup \\
\hline 4 & $1,6 \leq \bar{X}<3,2$ & Kurang \\
\hline 5 & $\bar{X}<1,6$ & Sangat Kurang \\
\hline
\end{tabular}

Kriteria keberhasilan aktivitas dalam penelitian ini apabila nilai aktivitas belajar siswa minimal berada pada kategori aktif.

b. Hasil Belajar Siswa

Hasil belajar siswa yang dianalisis diperoleh dari hasil LKS, kuis, observasi, dan tes akhir siklus. Hasil LKS, observasi, dan kuis diperoleh dari tiap pertemuan, sedangkan tes akhir siklus diperoleh pada akhir siklus. Ada tiga kriteria hasil balajar yang dinilai, yaitu rerata kelas, daya serap siswa, dan ketuntasan klasikal. 


\section{Rerata Kelas}

Diperoleh dengan rumus :

$$
\bar{X}=\frac{\sum X}{N}
$$

Keterangan:

$\bar{X} \quad=$ rerata kelas

$\sum X=$ jumlah seluruh skor siswa

$N \quad=$ banyaknya siswa

Kriteria : siswa dikatakan tuntas jika $\bar{X} \geq 75$

Daya Serap

Diperoleh dengan rumus :

$$
D S=\frac{\text { Nilai yang dicapaisiswa }}{\text { Nilai maksimum }} \times 100 \%
$$

Kriteria : siswa dikatakan tuntas jika DS $\geq 75 \%$

Ketuntasan Klasikal

$$
K K=\frac{\text { Jumlah } \text { siswa yang tuntas }}{\text { Jumlahsiswa }} \times 100 \%
$$

Kriteria : suatu kelas dianggap tuntas belajar bila mencapai KK $\geq 85 \%$

Jadi secara keseluruhan penelitian dikatakan berhasil apabila aktivitas dan hasil belajar siswa mencapai KKM yang ditentukan sekolah.

\section{HASIL DAN PEMBAHASAN}

\subsection{Hasil}

Berdasarkan hasil observasi yang dilakukan terhadap perkembangan aspek aktivitas belajar siswa selama pelaksanaan tindakan, diperoleh hasil seperti Tabel 4. 
Tabel 4. Perkembangan Aktivitas Belajar Siswa

\begin{tabular}{|c|c|c|c|c|c|}
\hline \multirow{3}{*}{ Interval } & \multirow{3}{*}{ Kategori } & \multicolumn{4}{|c|}{ Siklus I } \\
\hline & & \multicolumn{2}{|c|}{ I } & \multicolumn{2}{|c|}{ II } \\
\hline & & $\mathrm{F}$ & $\mathrm{P}(\%)$ & $\mathrm{F}$ & $\mathrm{P}(\%)$ \\
\hline $6,4 \leq \bar{x} \leq 8$ & Sangat Aktif & 0 & 0,0 & 17 & 42,5 \\
\hline $4,8 \leq \bar{x}<6,4$ & Aktif & 11 & 26,8 & 18 & 45,0 \\
\hline $3,2 \leq \bar{x}<4,8$ & Cukup & 16 & 39,0 & 5 & 12,5 \\
\hline $1,6 \leq \bar{x}<3,2$ & Kurang & 12 & 29,3 & 0 & 0,0 \\
\hline $\bar{x}<1,6$ & Sangat Kurang & 2 & 4,9 & 0 & 0,0 \\
\hline \multicolumn{2}{|c|}{ Rata-Rata Aktivitas Belajar } & \multicolumn{2}{|c|}{3,8} & \multicolumn{2}{|c|}{6,0} \\
\hline \multicolumn{2}{|l|}{ Kategori } & \multicolumn{2}{|c|}{ Cukup Aktif } & \multicolumn{2}{|c|}{ Aktif } \\
\hline
\end{tabular}

Keterangan :

$$
\begin{aligned}
& \mathrm{F}=\text { Frekuensi } \\
& \mathrm{P}=\text { Persentase }
\end{aligned}
$$

Dari tebel 4 di atas, diperoleh bahwa aktivitas belajar siswa pada siklus I belum memenuhi kategori keberhasilan karena hasil yang diperoleh 3,8 dengan kategori cukup aktif, sedangkan aktivitas belajar siswa pada siklus II sudah memenuhi kategori keberhasilan karena hasil yang diperoleh 6,0 dengan kategori aktif.

Sedangkan perkembangan hasil belajar siswa selama pelaksanaan tindakan diperoleh hasil seperti Tabel 5 berikut.

Tabel 5. Perkembangan Hasil Belajar Siswa

\begin{tabular}{|c|c|c|c|c|c|c|c|}
\hline \multirow{2}{*}{ No } & Siklus & $\begin{array}{c}\text { Rerata } \\
\text { Kelas }\end{array}$ & Kategori & $\begin{array}{c}\text { Daya } \\
\text { Serap } \\
(\%)\end{array}$ & Kategori & $\begin{array}{c}\text { Ketuntasan } \\
\text { Klasikal } \\
(\%)\end{array}$ & Kategori \\
\hline 1 & I & 77,0 & Tuntas & 77,0 & Tuntas & 68,3 & $\begin{array}{c}\text { Tidak } \\
\text { Tuntas }\end{array}$ \\
\hline 2 & II & 82,7 & Tuntas & 82,7 & Tuntas & 90,0 & Tuntas \\
\hline
\end{tabular}

Berdasarkan kategori keberhasilan penelitian maka hasil belajar siswa pada siklus I belum memenuhi kategori keberhasilan, karena belum mecapai ketuntasan secara klasikal, sedangkan pada siklus II sudah mencapai kategori keberhasilan karena sudah berada pada kategori tuntas. 


\subsection{Pembahasan}

Berdasarkan analisis aktivitas belajar siswa dapat dilihat bahwa terjadi peningkatan rata-rata aktivitas belajar siswa pada setiap pertemuan. Aktivitas belajar siswa yang dicapai siswa pada siklus I masih berada pada kategori cukup dengan rata-rata 3,8. Berdasarkan kategori keberhasilan, suatu penelitian dikatakan berhasil jika aktivitas belajar siswa minimal berada pada kategori aktif. Jadi pada siklus I ini, aspek aktivitas belajar siswa belum mencapai kategori keberhasilan. Ketidakberhasilan ini disebabkan oleh beberapa permasalahan yang terjadi selama tindakan siklus I seperti kurang aktifnya siswa didalam menanggapi permasalahan yang diberikan oleh guru, selain itu siswa juga masih malas untuk mengajukan permasalahan/bertanya kepada guru dan peneliti dalam mengatasi permasalahan yang dihadapi. Kendala lain yaitu kurangnya kerjasama dan kontribusi siswa dalam kerja kelompok serta inisiatif siswa didalam memanfaatkan sumber pembelajaran dalam memecahkan masalah masih rendah.

Permasalahan yang dihadapi tersebut, diatasi melalui tindakan perbaikan, yaitu melalui pemberian penekanan/imbauan tentang aspek-aspek aktivitas belajar siswa yang dinilai serta membagikan rubrik penilaian aktivitas belajar siswa, sehingga dapat memotivasi siswa untuk mampu bersaing dengan kelompok lainnya. Selain itu juga dilakukan pengurangan anggota kelompok, dengan tujuan untuk meningkatkan kontribusi dan kerjasama anggota kelompok pada kelompoknya.

Berdasarkan perbaikan yang dilakukan terhadap kekurangan selama siklus I, maka pada siklus II diperoleh peningkatan rata-rata aktivitas belajar siswa pada setiap pertemuan. Dari hasil analisis diperoleh bahwa rata-rata aktivitas belajar siswa pada siklus II diperoleh sebesar 6,0 dengan kategori aktif. Berdasarkan kriteria keberhasilan, suatu penelitian dikatakan berhasil jika aktivitas belajar siswa berada pada kategori aktif, dengan demikian tindakan yang dilakukan pada siklus II sudah berhasil dari segi aktivitas belajar.

Perbaikan tindakan pada siklus II menyebabkan adanya peningkatan aktivitas belajar siswa dari 3,8 dengan kategori cukup aktif pada siklus I menjadi 6,0 pada siklus II dengan kategori aktif. Keberhasilan tindakan dalam meningkatkan 
aktivitas belajar siswa disebabkan karena adanya rasa saling ketergantungan dan tanggung jawab dari setiap anggota kelompok untuk memajukan kelompoknya. Setiap anggota kelompok sadar bahwa untuk memperoleh yang terbaik dibutuhkan kerjasama dan kontribusi semua anggota kelompok, sehingga tercapai tujuan bersama. Keberhasilan tindakan dalam meningkatkan aktivitas belajar juga disebabkan karena pemberian kesempatan kepada siswa untuk mencari pengalaman sendiri dan langsung mengalami sendiri proses pembelajaran. Hal yang demikian tentunya akan mengembangkan pemahaman dan berfikir kritis siswa yang bermuara pada hasil belajar siswa.

Sedangkan untuk hasil belajar siswa yang diperoleh dari observasi yang dilakukan setiap pertemuan dan tes yang diberikan pada akhir pembelajaran dan akhir siklus diperoleh bahwa rata-rata hasil belajar siswa pada siklus I sebesar 77,0, daya serap siswa sebesar 77,0\% dan ketuntasan klasikal sebesar 68,3\%. Berdasarkan kategori keberhasilan, suatu penelitian dikategorikan berhasil apabila perolehan ratarata hasil belajar siswa minimal 75 , daya serap siswa minimal $75 \%$, dan dengan ketuntasan klasikal minimal 85\%. Dari kategori tersebut, diperoleh bahwa pelaksanaan tindakan siklus I belum mencapai kategori keberhasilan karena ketuntasan secara klasikal belum berhasil. Ketidakberhasilan tersebut disebabkan oleh beberapa permasalahan yang terjadi selama pelaksanaan tindakan siklus I, seperti perhatian siswa dalam mengikuti pembelajaran masih kurang, aktivitas siswa masih rendah, dan rendahnya kesiapan diri siswa dalam mengikuti pembelajaran.

Permasalahan yang terjadi selama pelaksanaan tindakan siklus I tersebut kemudian diperbaiki melalui pemberian perhatian khusus kepada siswa yang kurang memperhatikan proses pembelajaran, pemberian bimbingan yang lebih intensif kepada setiap kelompok dalam memecahkan permasalahan, menyampaikan hasil kerja kelompok untuk memotivasi siswa mendapatkan hasil yang lebih baik, membagikan rubrik penilaian hasil belajar, memberitahukan materi yang akan dibahas pada pertemuan selanjutnya, serta melakukan perombakan jumlah anggota kelompok. 
Berdasarkan perbaikan tindakan pada siklus I maka pada siklus II diperoleh peningkatan hasil belajar siswa setiap pertemuan baik itu rerata kelas, daya serap, maupun ketuntasan klasikal. Rata-rata hasil belajar siswa pada siklus II diperoleh sebesar 82,7, daya serap siswa sebesar 82,7\%, dan dengan ketuntasan klasikal sebesar 90,0\%. Berdasarkan kategori keberhasilan, suatu penelitian dikategorikan berhasil apabila perolehan rata-rata hasil belajar siswa minimal 75 , daya serap siswa minimal $75 \%$, dan dengan ketuntasan klasikal minimal $85 \%$. Dengan demikian, pelaksanaan tindakan pada siklus II sudah dapat dikategorikan berhasil.

Perbaikan tindakan pada siklus II menyebabkan adanya peningkatan hasil belajar siswa baik itu rata-rata hasil belajar, daya serap siswa, maupun ketuntasan klasikal. Rata-rata hasil belajar meningkat dari 77,0 pada siklus I menjadi 82,7 pada siklus II dengan kategori tuntas. Daya serap siswa meningkat dari 77,0\% pada siklus I menjadi $82,7 \%$ pada siklus II dengan kategori tuntas, sedangkan ketuntasan klasikal meningkat dari 68,3\% pada siklus I menjadi 90,0\% pada siklus II dengan katagori tuntas.

\section{PENUTUP}

Berdasarkan hasil penelitian dan pembahasan yang telah diuraikan, dapat disimpulkan bahawa implementasi pembelajaran kooperatif tipe STAD dapat meningkatkan aktivitas dan hasil belajar siswa kelas XI Bahasa ${ }_{1}$ SMA Negeri 3 Singaraja tahun ajaran 2009/2010.

Bertolak dari hasil refleksi dan temuan-temuan selama penelitian maka diajukan beberapa saran kepada guru atau peneliti lain yang akan melakukan penelitian sejenis agar memfasilitasi siswa dengan sumber pembelajaran serta menggunakan tipe pembelajaran kooperatif yang jumlah anggota kelompoknya lebih sedikit. Misalnya kooperatif tipe Think-Pair-Share (TPS), yang jumlah anggota kelompoknya berpasangan. Oleh karena tidak menutup kemungkinan akan diperoleh hasil penelitian yang berbeda, maka disarankan pula kepada guru atau peneliti lain 
untuk melakukan penelitian sejenis di sekolah/ kelas yang berbeda dengan pokok bahasan yang sama utau berbeda.

\section{DAFTAR PUSTAKA}

Arikunto, S. 2006. Penelitian Pendidikan Kelas. Jakarta: PT. Bumi Aksara.

Dimyati, Moh dan Moedjono. 1991. Strategi Belajar Mengajar. Jakarta: Depertemen Pendidikan dan Kebudayaan Direktorat Jendral Pendidikan Tinggi.

Dimyati, Moh dan Moedjono. 2002. Belajar dan Pembelajaran. Jakarta: PT.Rineka Cipta

Hamalik, Oemar. 2004. Kurikulum dan Pembelajaran. Jakarta: PT.Bumi Aksara.

Ibrahim, Muslimin, dkk. 2001. Pembelajaran Kooperatif. Surabaya: University Press.

Jurusan Pendidikan Teknik Informatika. 2009. Katalog Jurusan Pendidikan Teknik Informatika. Edisi 2009.Singaraja.

Kusumah, Wijaya dan Dedi Dwitagama. 2009. Mengenal Penelitian Tindakan Kelas. Jakarta: PT.Indeks.

Lie, Anita. 2005. Cooperative Learning. Jakarta: Gramedia.

Marlissa. 2005. Pemrograman Database Mahir Berbasis Acces 2002. Surabaya: INDAH Surabaya.

Nazir, Moh. 2003. Metode Penelitian. Jakarta: Ghalia Indonesia.

Nurhadi, dkk. 2004. Pembelajaran Kontekstual (Contextual Teaching and Learning/CTL) dan Penerapannya dalam KBK. Malang: Universitas Negeri Malang.

Permana, Budi. 2002. 36 Jam Belajar Microsoft Acces 2002. Jakarta: PT.Alex Media Komputindo.

Pujani dan Kade Suardana. 2007. Peningkatan Kualitas Perkuliahan Fisika Dasar 4 Melalui Pembelajaran Kooperatif Tipe STAD di Jurusan Pendidikan Fisika Undiksha. Laporan Penelitian. Universitas Ganesha Singaraja. 
Sanjaya, Wina. 2009. Strategi Pembelajaran Berorientasi Standar Proses Pendidikan. Jakarta: Kencana. 